Real wage cyclicality and the Great Depression: evidence from British engineering and metal working firms

Robert A. Hart

J. Elizabeth Roberts

Stirling Economics Discussion Paper 2011-09

May 2011

Online at http://www.management.stir.ac.uk/research/economics/workingpapers 


\title{
Real wage cyclicality and the Great Depression: evidence from British engineering and metal working firms
}

\author{
Robert A. Hart \\ Division of Economics \\ University of Stirling and IZA \\ Email: r.a.hart@stir.ac.uk \\ J. Elizabeth Roberts \\ Division of Economics \\ University of Stirling
}

May 2011

JEL Classification: E32, J31, J33, N64

Keywords: Real wage cyclicality, the Great Depression; piecework, timework, aggregation bias

Abstract: Based on firm-level payroll data from around 2000 member firms of the British Engineering Employers' Federation we examine the behavior of real hourly earnings over the 1927-1937 cycle that contained the Great Depression. The pay statistics are based on adult male blue-collar workers within engineering and metal working firms. They allow us to distinguish between pieceworkers and timeworkers and they are delineated by 14 occupations and 51 travel-to-work geographical engineering districts. We measure the cycle using national unemployment rates as well as rates that match our district breakdowns. Differences are found in the real hourly earnings cyclicality of pieceworkers and timeworkers. We attempt to relate our findings to those of modern micro panel data studies of real wage cyclicality. We offer some insight into why the estimates of real hourly pay display less procyclicality during the 1920 s and 1930s than in studies based on more recent data.

Acknowledgements: Work on this research was funded by ESRC Grant RES-000-22-3574. We are grateful to the Engineering Employers' Federation (EEF) for allowing access to their payroll records and to Warwick University Modern Record Centre and Glasgow University Archive Centre for their help in assembling the data. We thank Andrew Currall for transcribing the data. We also thank Paul Devereux, Olaf Hübler, Ryan Michaels, and Gary Solon for very helpful comments on earlier drafts. The full EEF data base, containing all EEF data and accompanying unemployment rates used in this project, is available at the UK Data Archive, Study 5569 (http://www.data-archive.ac.uk/searchStart.asp ). 


\section{Introduction}

The past two decades have witnessed an expanding agreement among empirical economists that real wages are procyclical. Before this time, there was a wide mix of opposing views. ${ }^{1}$ The emerging consensus has coincided with a growing emphasis on the use of micro longitudinal panels that have allowed researchers to tackle problems of aggregation biases. However, recent empirical developments stop short of embracing the most important and influental business cycle in modern economic history - the Great Depression cycle of the late 1920s to late 1930s. Due to a lack of individual-level data, we cannot investigate real wage behavior in the 1920s and 1930s with the equivalent power of modern micro studies. Nonetheless, given continued strong interest in the labor market effects of the early 1930s downturn, it remains important to move as far as possible in the direction of greater data disaggregation. To this end, we obtain estimates of British real wage cyclicality during the Great Depression using statistics that help us to get closer to more recent research. We make use of payroll data for around 2000 engineering and metal working member firms of the British Engineering Employers Federation.

Great Depression wage statistics featured as part of one of the earliest and best known debates on real wage cyclicality. In the General Theory (1936), Keynes conjectured that reductions in aggregate employment are likely to be associated with falls in money wages and rises in real wages. While labor is unlikely to resist money wage reductions during severe

\footnotetext{
${ }^{1}$ The earlier debates on the cyclical behavior of real wages in both the theoretical and empirical literature are usefully summarised in Bernanke and Powell (1986), Barsky and Solon (1989), Solon, Barsky, Parker (1994), Abraham and Haltiwanger (1995), and Swanson (2007).
} 
economic downturns, real wages would be expected to rise given decreasing marginal product. In other words, real wages should move countercyclically. ${ }^{2}$ The subsequent empirical research of Dunlop (1938) using British data and Tarshis (1939) using U.S. data found positive correlations between money and real wages. They argued that real wages were procyclical, a conclusion with which Keynes (1939) appeared to concur. ${ }^{3}$

Our payroll data are obtained from British engineering and metal working firms that are members of the Engineering Employers' Federation (EEF). Its primary focus is on the pay and hours of blue-collar workers. A big advantage of these statistics, even by modern standards, is that they distinguish between pieceworkers and timeworkers. Piece rates constituted a major payments method among British blue-collar inter-war occupations and comprise over half of workers in the EEF during the period of study. In fact, Britain was not the only European country in which pieceworking was prevalent in these industrial sectors during the Depression years. ${ }^{4}$ Our piece-rated and time-rated pay groups are further subdivided into 14 manual occupations and 51 EEF travel-to-work geographical districts.

${ }^{2}$ This view of real wage behavior was not only reflective of the earlier classical school but was also shared by Friedman (1968) and mainstream New Classical economists (see Carlin and Soskice, 1990, Chapter 16).

${ }^{3}$ Although this by no means represented an emerging consensus (Bodkin, 1969).

${ }^{4}$ For example, piecework featured prominently in German engineering and metal working firms during the 1920s and 1930s. The British Ministry of Labour Gazette (January 1933, p. 13) reports on a large enquiry, covering 214,000 workers and undertaken in October 1931 by the German Federal Statistical Office. It covered pay and hours in the German metal and engineering industries within 502 plants in 103 localities. It is reported that $65 \%$ of skilled and semi-skilled workers and $23 \%$ of unskilled workers were on piece-rates. In the October 1931 EEF returns, the respective percentages are $59 \%$ and $16 \%$. 
The predominant approach in the literature has been to concentrate on a national cyclical indicator, usually the rate of unemployment, to reflect business cycle effects that inform pay decisions. We too construct a national rate that matches EEF aggregate industrial coverage (see Figure 1). Our analysis concentrates on the period 1927 to 1937, representing the trough-to-trough cycle that includes the Depression years. However, collective bargaining within the Federation was conducted in a three-tier system - at national, district and firm levels. Since local product and labor markets played potentially important roles, we also accommodate district-level business cycle influences. To this end, we additionally undertake estimation using unemployment rates that match the EEF engineering districts.

Our payroll data comprise means of occupation-district cells that relate separately to pieceworkers and timeworkers. While they fall short of the modern-day gold standard of longitudinal individual survey data they at least move us nearer to that benchmark compared to earlier Depression studies. ${ }^{5}$ Our estimation strategy is as follows. First, we estimate real hourly earnings ${ }^{6}$ cyclicality using national- and district-level measures of the cycle. Second, we focus on the fact that our data, compared to individual-level panels, are likely to fall short of fully capturing aggregation biases. Based on the British New Earnings Survey Panel Dataset (NESPD) covering Britain's most cyclically volatile post-war period, 1975-1990, we attempt to assess the

${ }^{5}$ Bernanke and Powell provide an earlier well known attempt to achieve greater data disaggregation in their analysis of labor market cyclicality in the Depression years. Their monthly wages data for 12 industries also cover both pieceworkers and timeworkers although they do not attempt to separate these pay groups (see their Appendix, note 1, p. 618). These data are also used by Bernanke (1986) where it is also noted (p. 106) that separation is not attempted.

${ }^{6}$ Our earnings measures include the influence of overtime working. 
degrees to which our occupation/district- based estimates are likely to diverge from comparable estimates using individual-level data. Third, we report briefly on one further potentially important issue. We investigate the cyclicality of real weekly wages during the Great Depression. We show that changes average hours played an especially important role among 1930s British manufacturing firms in adjusting their labor inputs. Such a role has been less significant in more recent times.

\section{Payment methods, and the structure of collective bargaining}

\section{Piece work and time work}

Between 1927 and 1937, 53\% of the British EEF workforce was paid piece rates and 47\% time rates. There are four strong reasons for separating timeworkers and pieceworkers in the study of wage cyclicality.

i) Since in the short-term piece-rated pay is linked more closely to output than time-rated pay, we might expect the former to exhibit more responsiveness to business cycle fluctuations than the latter. Based on the Panel Study of Income Dynamics (PSID), Devereux (2001) finds that hourly earnings responses of individuals whose pay is linked directly to output (including piece-rates) are significantly more procyclical than those of hourly paid and salaried workers. Using pre- and post-war EEF data, Hart (2008) also finds significantly greater inter-war hourly wage procyclicality among pieceworkers compared to timeworkers, though less pronounced than in Devereux's study. 
ii) As we discuss in Section 5, within-occupation heterogeneity may take the form of greater wage procyclicality among lower-ability, lower-paid workers. This introduces a well-known form of countercyclical bias to aggregate wages (Stockman, 1983; Solon, Barsky and Parker, 1994). Ceteris paribus this problem may be greater among pieceworkers than timeworkers.

Piece work entails a requirement to monitor each individual's output per period and thereby provides records on which systematically to rank employees, or work groups, by productive performance

iii) Both timeworkers and pieceworkers were eligible to work overtime hours paid for at highly favorable premium rates. ${ }^{7}$ Procyclical working hours of timeworkers correlate positively with both weekly pay and, given overtime working, hourly pay. In other words, the intensive margin effects of hours on the hourly pay of timeworkers are unequivocally procyclical. ${ }^{8}$ In contrast, the intensive margin effects on the cyclicality of piecework pay

\footnotetext{
${ }^{7}$ Throughout all EEF member firms, weekly standard hours were divided into 'standard days' (5 weekdays and Saturday mornings) and overtime pay applied to daily hours in excess of the laiddown standard daily hours. Both timeworkers and pieceworkers received premium pay for overtime hours. The calculation for a pieceworker was based on a mark-up of his so-called minimum piecework standard. From 1920 to 1930, overtime was typically paid at time and a half 'basic' rates if worked on Mondays to Saturdays and at double time for Sundays and public holidays. From 1931 to 1946, the first two hours of daily overtime were paid at time and a quarter and subsequent hours at time and a half. The rules of overtime payments are described in detail in Knowles and Hill (1954).

${ }^{8}$ Let hourly earnings $e$ be expressed as a geometric average, with $w$ representing the standard hourly rate and the overtime premium fixed at $\mathrm{k}_{0}$ (e.g. one-and-a-half times the standard rate). We have $e=w^{\lambda}\left(k_{0} \cdot w\right)^{(1-\lambda)}$ where $\lambda=h_{s} / h \leq 1$ and where $(1-\lambda)$ is the share of standard weekly hours $\left(h_{s}\right)$ to total hours. Let the rate of unemployment, $U$, proxy the cycle. Then, taking logs, rearranging, and expressing in terms of time $t$, differentiation with respect to $U_{t}$ yields: $d \log e_{t} / d U_{t}=d \log _{t} / d U_{t}+\log k_{0}\left[d\left(1-\lambda_{t}\right) / d U_{t}\right]$. Since the share of overtime, $\left(1-\lambda_{t}\right)$, is procyclical this increases the procyclicality of hourly wage earnings compared with hourly wage rates.
} 
are uncertain. They depend on a combination of length of working hours and effort per hour and, therefore, on whether these two variables act as complements or substitutes. ${ }^{9}$

iv) During a cyclical downturn, actual pay of skilled workers may be less responsive to the cycle than that of less skilled if firms show a propensity to hoard skilled labor inputs in order to protect sunk human capital investments. ${ }^{10}$ However, this effect is likely to be less potent in the case of piece work where pay relates directly to actual productivity per period. In other words, the distinction between paid for and effective working time is less meaningful when remuneration is linked directly to performance.

National bargaining, district bargaining, and the cycle

Wage rate setting within the EEF was subject to a three-tier bargaining process, embracing national- ${ }^{11}$, district- and firm-level employer-union negotiations. National agreements determined annual standard time rates for skilled fitters and laborers. These were then used throughout the Federation to establish relative wages for other skill groups. But

\footnotetext{
${ }^{9}$ This problem has been analysed more formally via a labor supply model (Pencavel, 1977) and a union-employer bargaining model (Hart, 2008).

${ }^{10}$ For example, skilled fitters in the EEF would normally have served a 5-7 year apprenticeship in sharp contrast to laborers who required minimal training.

${ }^{11}$ Engineering pay setting during WWI had a major bearing on tendencies towards nationallevel bargaining in later years. The National Wages Agreement of 1917 introduced an arbitration system that adjudicated three times a year in respect of national uniform wage increases as well as engineering district rates. Although the Agreement ceased in 1920, national-level bargaining continued up to 1948. Also during WWI, a bonus was granted to engineering workers due to the increased cost of living during the war. This was intended to be a temporary measure but, although significantly reduced in 1922, it continued to be paid over the inter-war period.
} 
subsequent district-level and firm-level bargaining produced a multiplicity of deviations from these national rates in order to accommodate local market conditions. Even with piece rates, involving a far more complex remuneration structure, there were national-level attempts at establishing pricing guidelines. ${ }^{12}$

Given the national bargaining tier, we follow most of the wage cyclicality literature by using the national unemployment rate to represent the influence on real wages of the nationwide macro business cycle. However, we know that for both wage rates and piece rates local bargaining contributed importantly to final pay settlements. ${ }^{13}$ Moreover, in important respects, local collective bargaining was conducted in distinctly different product and labor markets. Older traditional engineering industries (such as textile engineering, heavy engineering, marine engineering) were concentrated in the north of Britain, with specific industries tending to cluster in specific districts. Midland and southern engineering districts, by contrast, enjoyed significant concentrations of modern industries (car manufacture, aircraft construction, related light engineering), again with high degrees of specific geographical

12 Based on a worker with 'average ability', national agreements established a percentage mark-up that a pieceworker might be expected to earn compared with the standard time rate within the same occupation. As with time rates, however, local conditions dictated that piece rates, as well as piece rate - time rate differentials, varied substantially within firms, across firms and through time.

13 Knowles and Hill (1954) succinctly summarise the position for each payment method. In the case of time rates, they conclude: "All rates fixed by national agreement are essentially minima, the national-agreed differentials may be disturbed or even inverted by firms paying more than the minima all round". For piece rates, they conclude: "Owing to the immense number of different processes and operations in so heterogeneous an industry, as well as to the rapidity of technical development, any general control over piece-work earnings can be no more than minimal..." 
clustering. Accordingly, we also study the influence of local labor market conditions, as proxied by district unemployment rates, on pay cyclicality.

\section{The Engineering Employers' Federation Payroll Data: 1927-1937}

The EEF is the largest sectoral employers' organisation in the United Kingdom with a current membership of nearly 6000 firms. From 1926 to 1968, the Federation asked each of its members to conduct annual earnings enquiries based on its payroll records. During our period of study, the Federation represented between 1,800 and 2,200 firms employing between 390,000 and 520,000 adult male manual workers (Wigham, 1973, Appendix, J). It embraced a wide range of engineering, metal, aircraft, and automotive sections of industry. In the interwar period the total of these sections (i.e. EEF and non-EEF firms) accounted for about $25 \%$ of British manufacturing. Of this $25 \%$, EEF firms represented about $30 \%$. Our recorded data cover between $10 \%$ and $15 \%$ of this EEF share. ${ }^{14}$

Statistics cover a specimen week in each October and we concentrate on manual males over the age of 21. The payroll statistics were collected, in part, for the purpose of being of direct use in employer-union negotiations at national, district, and section levels. Virtually all member firms were unionized ${ }^{15}$ and somewhat skewed towards larger employers. ${ }^{16}$ Table 1

\footnotetext{
${ }^{14}$ We have checked that our annual wages and hours measures tally very closely with those supplied by the Federation to the Ministry of Labour - and used in the official statistics of the Ministry of Labour Gazette to cover British wage payments in engineering and metal working.

${ }^{15}$ Wigham (1973) indentifies three union-related basic functions of the Federation. First, it provided collective support in order to protect individual firms from being singled out in union
} 
identifies the EEF occupations, geographical districts, and engineering sections. There are 14 blue-collar occupations and 51 engineering districts. For a shorter time period, we also have data for 28 engineering sections. ${ }^{17}$ Table 2 indicates the average number and standard deviation of workers (summed across all occupations by each payment method) in each district over the entire period of study and over the Depression years. There are wide variations in these numbers, ranging from 1800 in London to 57 in Wigan.

Table 2 also presents a summary of the hours' statistics for the whole period. Average weekly total and overtime hours of timeworkers are higher than their pieceworker equivalents. However, it is clear from the standard deviations that there were wide variations around these means. Over the entire period, pieceworkers averaged 0.5 hours above the maximum 47 standard weekly hours and timeworkers 2.1 hours above. During the Depression years (193033) the respective deviations were -1.8 and -0.5 hours while in the post-Depression years (1934-37) they were 1.8 and 3.7 hours. Although on average short-time workweeks applied during the Depression years, we note that average overtime remained positive throughout.

actions. Second, it aimed to preserve the relative power of employers to make management decisions. Third, it helped towards conflict resolution in union disputes.

${ }^{16}$ Hill and Knowles (1956) have undertaken a detailed analysis of the 1953 membership of the EEF. They show that while 50.7 of federated firms employed fewer than 100 workers, they accounted for only 6.2 per cent of total employment. By contrast, the 1.8 percent of firms that employed over 3,000 workers accounted for $27 \%$ of total employment.

${ }^{17}$ We do not have section-level statistics by district. Including first differencing, district-level breakdowns are available for the whole 1927 - 1937 cycle. The section-level data are only available from 1930 and so allow analysis from 1931 to 1937 . We have undertaken all the later empirical work at section level, obtaining results that are largely in line with our findings based on the full cycle of district-based data. We concentrate here on our superior data set. 
This is because some engineering districts worked overtime even during the depth of the economic cycle. Differences in working time at district level for a sample of five districts are illustrated in Figure 2 in respect of timeworkers. In the relatively prosperous midlands and southern districts of Coventry and London - where modern light engineering, automotive and aircraft firms clustered - average weekly hours always exceeded the maximum standard hours. In the north, large cities like Liverpool averaged hours slightly below 47 during the trough years. Other northern districts, like Dundee and Halifax, experienced large reductions in hours below the 47 standard hours ceiling. Figure 3 shows the share of overtime within total hours for three important occupations - time-rated turners, sheet metal workers, and laborers. The shares are strongly procyclical.

Against the background of manufacturing unemployment, Figure 4 provides an aggregate summary of pieceworkers' and timeworkers' hours and pay (nominal and real) as well as final output and retail price deflators over the period 1927 to 1937 . Average weekly hours of both groups are strongly procyclical. On the downside of the cycle and towards the end of the cycle, pieceworkers' weekly hours were considerably below those of timeworkers. Final output and retail prices fell significantly between 1928 and 1934 - by $13.5 \%$ and $12.1 \%$, respectively. Nominal hourly earnings of pieceworkers declined during the early years of the Depression while equivalent earnings of timeworkers were flat. Price deflation ensured that average real hourly earnings of pieceworkers were very slightly positive in the early years while those of timeworkers displayed more appreciable growth. Due to the large aggregate downward movement in weekly hours, nominal weekly earnings of both groups are clearly procyclical, although somewhat less markedly so in the case of timeworkers. Real weekly 
earnings of pieceworkers appear procyclical at this aggregate level. For timeworkers, real weekly earnings fell slightly between 1929 and 1930 and thereafter were flat before displaying annual growth. ${ }^{18}$

As identified in Table 2, we have matching unemployment rates for 29 of our 51 engineering districts. ${ }^{19}$ These include virtually all the main centers of engineering, metal working, automotive and aircraft industries and comprise $84.8 \%$ of the total EEF workforce recorded in our data set. Figure 5 shows, for the same sample of districts as in Figure 2, wide diversities among local unemployment rates. London and Coventry rates never exceeded $20 \%$ while Dundee and Halifax reached rates in excess of $35 \%$.

${ }^{18}$ Table 2 shows the piecework-timework hourly earnings differentials for the period, together with the changes in weekly hours and real weekly earnings for the two groups of workers. Average hourly earnings of pieceworkers were $25 \%$ higher than timeworkers over the period. A positive earnings differential is a common finding in the literature (e.g. Pencavel, 1977; Seiler, 1984). Note, however, that this aggregate figure is not comparing like-with-like jobs. One major influence is structural. There was a greater incidence of pieceworking in the more modern/higher wage firms located in southern/midland districts. In our complete data, $43 \%$ of workers in northern districts worked on piece rates compared to $63 \%$ in south/midlands districts. In general, however, the differential is broadly similar to other findings. For example, Ainsworth (1949, Appendix VII) finds a piecework-timework differential of $30 \%$ in 1938 for British metal, engineering and shipbuilding industries.

${ }^{19}$ Most of the district unemployment rates are obtained from Hart and MacKay (1975). They were constructed to coincide with EEF districts by combining data on male unemployment and total insured workers taken from the Local Unemployment Index. A few district series are obtained from issues of the Ministry of Labour Gazette. 


\section{Hourly real wage cyclicality}

We begin by providing a benchmark specification. We construct an aggregate measure of annual average hourly earnings that covers the complete EEF. It is equivalent to taking all member firms' total weekly payroll divided by their total paid-for hours. Summing across our 51 districts and 14 occupation groups (see Table 1), we have

(1) $E_{t}=\sum_{r=1}^{51} \sum_{i=1}^{14}\left(H_{i r t} / H_{t}\right) E_{i r t}$

where $r$ indexes districts, $i$ indexes occupations, $H_{\text {irt }}$ is total work hours in the $i^{\text {th }}$ occupation ${ }^{20}$ in district $r, E_{i r t}$ is average real hourly earnings in the $\mathrm{i}^{\text {th }}$ occupation in district $r$, and $H_{t}=\sum_{r=1}^{51} \sum_{i=1}^{14} H_{i r t}$

We adopt the statistical model of Barsky and Solon (1989) as the basis of our estimating equations for the influence of the change in unemployment on the change in real hourly earnings. So, our first specification, at aggregate EEF level, takes the form

(2) $\Delta \log E_{t}=\alpha_{0}+\alpha_{1} t+\alpha_{2} \Delta U_{t}+\varepsilon_{t}$

where $t$ is a time trend and $\Delta U_{t}$ is the differenced national unemployment rate. In this and all susbsequent regressions we multiply the earnings variable by 100 so that we can interpret the estimated unemployment coefficient as the percentage change in real earnings resulting from a one point increase in the rate of unemployment.

\footnotetext{
${ }^{20}$ That is, average weekly hours multiplied by the number of workers in the occupation.
} 
We can improve on the specification in (2) by controlling for occupation and district composition effects. If, for example, the shares of total hours of low-wage occupations and/or low-wage districts are more cyclically sensitive than their high-wage equivalents then this would impart a countercyclical bias to the aggregate wage statistic incorporated in (2) (see Chirinko, 1980 in an industry context). To counter this potential problem, our second specification disaggregates the data to include real hourly earnings broken down by occupations and districts, but retaining the change in the national unemployment rate to represent the influence of the cycle. We adopt the by now familiar two step estimation method (e.g. Devereux, 2001) to correct for downwardly biased standard errors resulting from using a wage variable that is more disaggregated than the cyclical indicator (Moulton, 1986).

In step 1 we have

(3) $\Delta \log E_{\text {irt }}=\boldsymbol{d}_{\boldsymbol{o}}+\boldsymbol{d}_{\boldsymbol{r}}+\sum_{t=1}^{11} \beta_{t} d_{t}+\varepsilon_{i r t}$ where $\boldsymbol{d}_{\boldsymbol{o}}$ is a set of occupation dummies, $\boldsymbol{d}_{\boldsymbol{r}}$ is a set of district dummies and where $d_{t}$ is a time dummy equal to 1 if the observation is from year $t$. The estimated coefficients on the time dummies, $\hat{\beta}_{t}(t=1, \ldots, 11)$, are regressed in step 2 on the change in the national unemployment rate and a time trend, that is

(4) $\hat{\beta}_{t}=\gamma_{0}+\gamma_{1} t+\gamma_{2} \Delta U_{t}+\varepsilon_{t}$.

We estimate (3) by OLS and (4) by WLS where the weights in the second stage are the number of individuals represented in each year.

Our data stop short of allowing us to control for potential composition biases arising from within-occupation heterogeneity. In the following Section, we attempt to assess the 
possible quantitative implications of this omission for our estimated EEF-based wageunemployment semi-elasticities.

Our third specification recognises district-specific bargaining and incorporates district unemployment rates as the representation of local cyclical influences. We make use of the 29 districts for which we have matching district unemployment rates (see Table 1). Since we are using occupational breakdowns, we continue to have a clustering problem using district rates: within a given district different occupations may share common components of variance that are not captured by the district rate. So, we again adopt the 2-step method. Step 1 is given by

(5) $\Delta \log E_{i r t}=\boldsymbol{d}_{\boldsymbol{o}}+\sum_{t=1}^{11} \sum_{r=1}^{29} \theta_{r t} d_{r t}+\epsilon_{i r t}$ where $\boldsymbol{d}_{o}$ is a set of occupational dummies, $d_{\mathrm{rt}}$ is a district dummy that takes the value of 1 for district $r$ at time $t$ (over 29 districts and 11 time periods). In step 2, estimates of $\theta_{r t}$ are regressed on the change in district-level unemployment rates plus district and time intercepts (6) $\hat{\theta}_{r t}=d_{r}+d_{t}+\pi \Delta U_{r t}+\varepsilon_{r t}$.

Therefore, we account for occupation, district, and time fixed effects. Examples of district effects include industrial composition, the vintage of capital, occupational skill-mix, the strength of union representation. We estimate (5) by OLS and (6) by WLS where the weights in the second stage are the number of individuals in each district in each year.

Semi-elasticities between real hourly earnings and unemployment changes resulting from each of the above three specifications are reported in Table 3. Real wages in regressions 
incorporating national unemployment rates are based on either a consumer price deflator or a final output price deflator. It is well known that results can be sensitive to the choice of deflators though observed differences are not systematic through time or from study to study (see Geary and Kennan, 1982; Bernanke and Powell, 1986; Abraham and Haltiwanger, 1995). In the event, however, there are no statistical differences between the two sets of real wage outcomes. In the case of district-level regressions, district and year dummies in equation (5) serve to control for price levels.

Based on our fully aggregated real hourly earnings measure, pieceworker results in row 1 display significant real wage procyclicality, albeit with small estimated elasticities. A one point increase in the rate of unemployment is associated with a real hourly earnings fall of between $0.2 \%$ and $0.3 \%$. This result persists, with marginally increased elasticities, in the following two pieceworker specifications shown in rows 3 and 5 . These break down the data into occupation/district cells and incorporate, respectively, the national unemployment rate and the district rates. ${ }^{21}$ Whether we assume national or local pay bargaining, the real hourly earnings of pieceworkers are significantly, though modestly, procyclical.

The aggregate results for timeworkers in row 2 display acyclical real hourly earnings responses. Statistically, this remains the case in rows 4 and 6 when disaggregating by

\footnotetext{
${ }^{21}$ Based on the U.S. Panel Study for Income Dynamics (PSID), Swanson (2007, Table 1) finds that, unlike using the change in the national unemployment rate, there are no significant unemployment effects on the first-differenced real hourly wage when local area unemployment rate changes are incorporated into his analysis. He suggests that one reason for this finding stems from the fact that measurement error is almost certainly a problem with U.S. local unemployment statistics. By contrast, the district rates used here involved careful matching of local employment exchange boundaries with the EEF districts by the Department of Employment (see Hart and MacKay, 1975).
} 
occupations and districts and incorporating either the national or the district unemployment rates. We note, however, that the point estimates based on the national unemployment rate move far more towards their equivalent pieceworker outcomes.

\section{Composition bias at individual level}

We obtain evidence of modest real hourly earnings procyclicality for pieceworkers and acyclical timeworker responses. These outcome compare with estimates of between $1 \%$ and 3\% in modern North American and European individual-level longitudinal micro studies (see Pissarides, 2009, Tables II and III for useful summaries). To what extent, if at all, does our inability to tackle potential composition biases due to within-occupation heterogeneity account for differences between our Great Deprssion estimates and those of more recent times? If, for example, the hours of relatively high paid workers within occupations are less procyclical then this would impart an unobserved countercyclical bias in our occupation-level estimates.

Evaluating the likely impact of individual-related composition bias requires an indirect approach. To this end, we use data from the British New Earnings Survey Panel Dataset (NESPD) for the years 1975 to 1990 . The NESPD comprises an individual-level random sample of $1 \%$ of the entire British workforce, with wage data obtained (by legal requirement) from firms' payrolls. The same data comprise part of the dataset used by Devereux and Hart (2006) who provide full background descriptive details. The years are selected for two reasons. First, they cover the most volatile period, in terms of aggregate unemployment changes, in British post-war history (see Devereux and Hart, Figure 1). Second, they contain an unbroken and 
comprehensive classification of 3-digit occupations. ${ }^{22}$ We concentrate of full-time males.

Earnings are deflated by the British Consumer Price Index.

As with our EEF data, we begin by constructing an aggregate NESPD measure of real hourly earnings, expressed

(7) $E_{t}=\sum_{j=1}^{N}\left(H_{j t} / H_{t}\right) E_{j t}$

where $j$ indexes individual workers, $H_{j t}$ is the $j^{\text {th }}$ worker's hours at time $t, E_{j t}$ is the $j^{\text {th }}$ worker's average hourly earnings, and $H_{\mathrm{t}}$ is individuals' hours summed over all individuals. In line with the structure of equation (2), we regress the change in the log of this aggregate earnings rate on a constant, a time trend and the change in the national rate of unemployment (using the same claimant count unemployment measure as in Devereux and Hart, 2006).

In order to assess likely degrees of bias remaining after controlling for occupations but not for within-occupation heterogeneity, we adopt the following strategy. We regress the level of the log real hourly earnings on a constant, dummies delineating 3-digit occupations, a time trend, and the aggregate unemployment rate. We compare outcomes with a second regression in which we drop the occupation dummies but include individual worker fixed effects. ${ }^{23}$ This comparison, together with the aggregate equation, is underaken with respect to all male

22 The classification was altered in 1991.

${ }^{23}$ It is common to include worker experience in individual fixed effects panel specifications. This is not possible with the NESPD and so, in line with Devereux and Hart (2006), we added a cubic in age. This has virtually no effect of the estimated semi-elasticities and we do not include the age dummies in our reported results. 
workers in the sample years as well as with respect to a 1-digit occupation sample of male plant and machine operatives. The latter contains some of the 3-digit occupations of our EEF study as part of its coverage and is reasonably close as a sample match.

Results are reported in Table 4. Based on our aggregate earnings measure in (7), both the full NESPD sample and the plant/machine operatives sample yield a semi-elasticity of -1.8 . Using individual fixed effects, the respective estimates rise to -2.5 and -2.2 . Replacing individual fixed effects with occupation dummies reduces the semi elasticities by about $15 \%$ to 2.2 in our total sample. Restricting observations to plant and machine operatives produces virtually no differences in these comparative semi-elasticities: -2.2 and -2.1 , respectively. ${ }^{24}$

At least based on this evidence, the use of 3-digit occupation breakdowns would appear to move us reasonably close to estimates based on individual worker fixed effects. In other words, they give support for the contention that our EEF results of Section 4 would not be radically altered if we could have accounted for within-occupation heterogeneity.

\section{Intensive margin adjustments of labor inputs in the Great Depression}

Comparisons between wage-unemployment trade-offs using individual-level longitudinal panels and earlier more aggregative studies have largely been conducted in terms

\footnotetext{
${ }^{24}$ There are clear NESPD differences in the cyclicality of occupation employment. For example, we regressed the ratio of managerial and professional employment (high pay) to total employment on a constant, time trend and the first-difference in unemployment. The estimated coefficient on the unemployment variable is $0.005(0.001)^{* *}$, that is significantly countercyclical. The same regression based on the plant and machine operatives (low pay) yields $-0.0007(0.0002)^{* *}$, a procyclical effect. We would expect the share of high wage employment to rise in a recession and low wage employment to fall.
} 
of real hourly earnings. Our findings strongly suggest that real hourly earnings during the Depression years in Britain were decidedly less procyclical than found in more contemporary studies. Geary and Kennan (1982) and Bils (1985) have noted that real wage behavior over the business cycle can be highly dependent on sampling period. Comparing the 1920s and 1930s with the decades starting 40 years later provides at least one labor market explanation as to why we might expect contrasting real earnings cyclical behavior.

Many firms faced with a severe economic downturn would want to reduce their labor inputs, and associated payroll costs, through extensive and intensive margin labor adjustments. Among other actions, they can layoff workers and they can reduce the per-period working hours of existing workers. During the 1930 s there may have been a greater emphasis on intensive margin adjustments. Social welfare provision in the earlier era was far less comprehensive and generous than in current times. Especially given the earlier prevalence of large unions and firm-union collective bargaining, there may well have been a greater joint willingness to share the burden of labor reductions between layoffs and hours cuts. We have seen in Section 3, that workweek reductions were quite considerable in the EEF, especially in the older traditional industries of the North of England and Scotland.

Returning to our 1975-1990 NESPD sample we show, in the last row of Table 4, fixed effects regressions using real weekly earnings in place of real hourly earnings. The changes in estimated semi-elasticities compared to their hourly equivalents in row 2 are quite marginal: from -2.5 to -2.7 for all male workers and from -2.2 to -2.4 for plant and machine operatives. Contrast these findings with the results shown in Table 5 in which we replicate the EEF hourly 
real earnings estimates in Table 3 by their weekly equivalents. For the aggregated data, in rows 1 and 2, the estimated semi-elasticities of both timeworkers and pieceworkers are around -0.7 to -0.8 . Decomposing earnings changes by occupations and districts in rows 3 and 4 , and retaining national unemployment changes, produces semi-elasticities of about -1 for both work groups. This degree of real weekly earnings cyclicality is on a par with the lower end of the spectrum obtained in modern micro studies in respect of real hourly earnings. Estimates using district unemployment rates in rows 5 and 6 are somewhat lower but now include significant timeworker effects. Overall, estimates of the cyclicality of real weekly earnings in the Depression years are between 2 and 4 times the magnitudes of comparable real hourly earnings.

\section{Conclusions}

For core sections of Britain's largest and most important industrial sector in the $1920 \mathrm{~s}$ and 1930s, we produce evidence on real wage cyclicality during the Great Depression based on greater levels of data disaggregation than achieved in most preceeding studies. However, our occupation/district breakdowns fall short of disaggregation achieved in modern micro panels. We attempt to bridge this gap by assessing the extent of likely aggregation bias remaining in our data.

In terms of the Tarshis-Dunlop-Keynes debate, we reject the notion of countercyclical real wages in British engineering and metal working during the Depression cycle. For pieceworkers, who comprise over half of the blue collar workforce in our data, we find support 
for significant, though modest, real hourly wage procyclicality. This is true whether we use national level unemployment to represent national pay bargaining influences or district rates to capture local agreements. It remains true even if we aggregate our pieceworker earnings data across our occupation and district cells. Timeworkers real hourly earnings, by contrast, are acyclical. From our individual-level panel data for a more recent volatile unemployment period (1976-1990), we find that using occupation dummies produces modest reductions in estimated earnings-unemployment elasticities compared to controlling for individual fixed effects. We conclude that our low semi-elasticities for the Depression years are likely to be reasonably reflective of aggregation bias-free estimates.

Beyond this, and corresponding to U.S. evidence presented by Bernanke and Powell (1986), we show that procyclicality in real weekly earnings was an important feature of firms' payroll adjustments in respect of both pieceworkers and timeworkers during the Depression years. Firms and workers appeared to be more willing to undertake intensive margin labor adjustments in the 1930s compared to those represented in our panel estimates of the more recent period. 


\section{References}

Abraham, K G and J C Haltiwanger. 1995. Real wages and the business cycle. Journal of Economic Literature 33: 1215-1264.

Ainsworth, R B 1949. Earnings and working hours of manual wage-earners in the United Kingdom in October, 1938. Journal of the Royal Statistical Society (Series A) 112, 35-66.

Barsky, R and G Solon. 1989. Real wages over the business cycle. NBER Working Paper, No. 2888.

Bernanke, B S 1986. Employment, hours, and earnings in the Depression: an analysis of eight manufacturing industries. American Economic Review 76: 82-109.

Bernanke, B S and J Powell. 1986. The cyclical behavior of industrial labor markets: a comparison of the pre-war and post-war eras. In R.J. Gordon, ed., The American business cycle: continuity and change. Chicago: University of Chicago Press.

Bils, M J 1985. Real wages over the business cycle: evidence from panel data. Journal of Political Economy 93, 666-689.

Bodkin, R G 1969. Real wages and cyclical variations in employment: a re-examinationof the evidence. Canadian Journal of Economics 2, 353-374.

Carlin, W and D Soskice. 1990. Macroeconomics and the wage bargain. Oxford: Oxford University Press.

Chirinko, R S. 1980. The real wage rate over the business cycle. Review of Economics and Statistics 62, 459-461.

Devereux, P J. 2001. The cyclicality of real wages within employer-employee matches. Industrial and Labor Relations Review 54, 835-850.

Devereux, P J and R A Hart. 2006. Real wage cyclicality of job stayers, within-company job movers, and between-company job movers. Industrial and Labor Relations Review 60, 105-119. 
Dunlop, J T. 1938. The movement of real and money wage rates. Economic Journal 48, 413-434.

Feinstein, C H. 1972. National income, expenditure and output of the United Kingdom 18551965, Cambridge, Cambridge University Press.

Friedman, M. 1968. The role of monetary policy. American Economic Review 58, 1-17.

Geary, P T and J Kennan. 1982. The employment-real wage relationship: an international study, Journal of Political Economy 90, 854-871.

Hart, R A. 2008. Piece work pay and hourly pay over the cycle. Labour Economics 15, 1006-1022.

Hart, R A. and D I MacKay. 1975. Engineering earnings in Britain, 1926-1938. Journal of the Royal Statistical Society (Series A) 138, 32-50.

Hill, T P. and K G J C Knowles. 1956. The variability of engineering earnings, Bulletin of the Oxford University Institute of Statistics 18, 97-139.

Keynes, J M. 1936. The general theory of employment, interest, and money. London: Macmillan.

Keynes, J M. 1939. Relative movements of real wages and output. Economic Journal 49, 34-51.

Knowles, K G J C and Hill, T P 1954. The structure of engineering earnings. Bulletin of the Oxford University Institute of Statistics 16, 272-328.

Moulton, B R. 1986. Random group effects and the precision of regression estimates. Journal of Econometrics 32, 385-397.

Pencavel, J. 1977. Work effort, on-the-job screening, and alternative methods of remuneration, Research in Labor Economics 1, 225-258.

Pissarides, C A. 2009. The unemployment volatility puzzle: is wage stickiness the answer? Econometrica 77, 1339-1369.

Seiler, E. 1984. Piece rate vs. time rate: the effect of incentives on earnings, The Review of Economics and Statistics, 66 363-376.

Solon, G, R B Barsky and J A Parker. 1994. Measuring the cyclicality of real wages: how important is composition bias? Quarterly Journal of Economics 109, 1-26.

Stockman, A C. 1983. Aggregation bias and the cyclical behavior of real wages, unpublished. 
Swanson, E T. 2007. Real wage cyclicality in the Panel Study of Income Dynamics. Scottish Journal of Political Economy 54, 617-47.

Tarshis, L. 1939. Changes in real and money wages. Economic Journal 49, 150-54.

Wigham, E. 1973. The power to manage. A history of the Engineering Employers' Federation. London: Macmillan. 
Figure 1 National-level unemployment rates, 1926 - 1938 (EEF aggregated district rates)

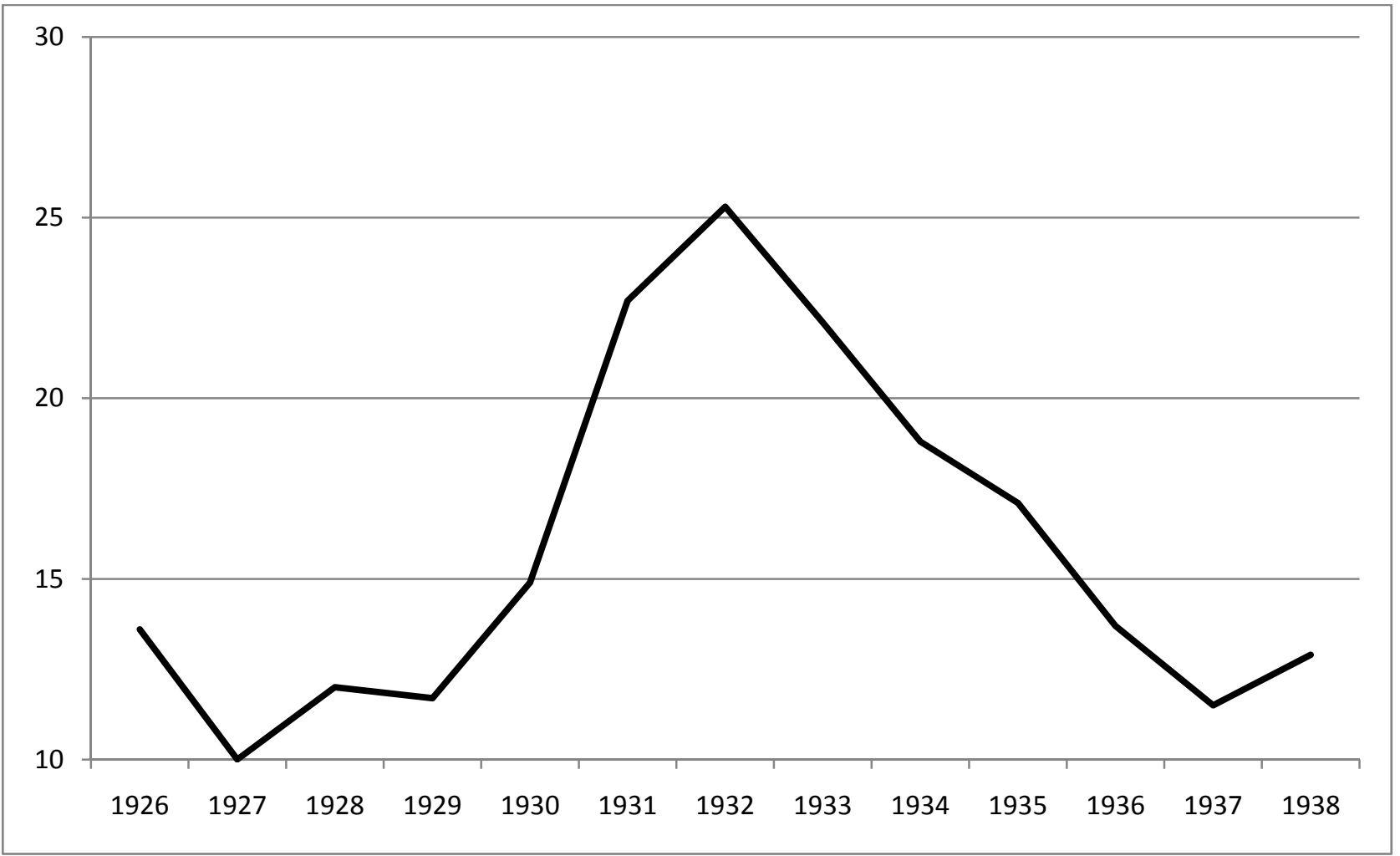




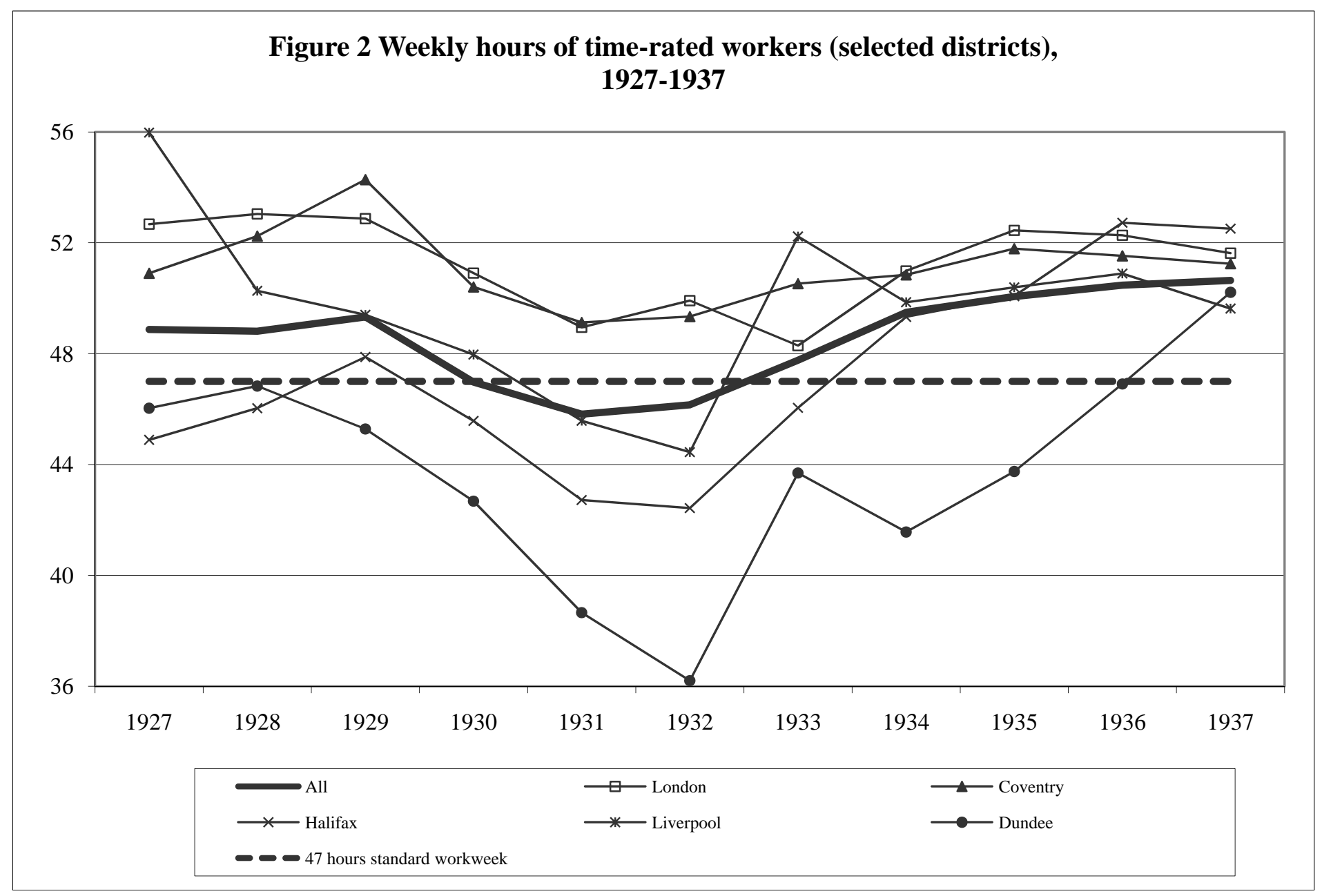




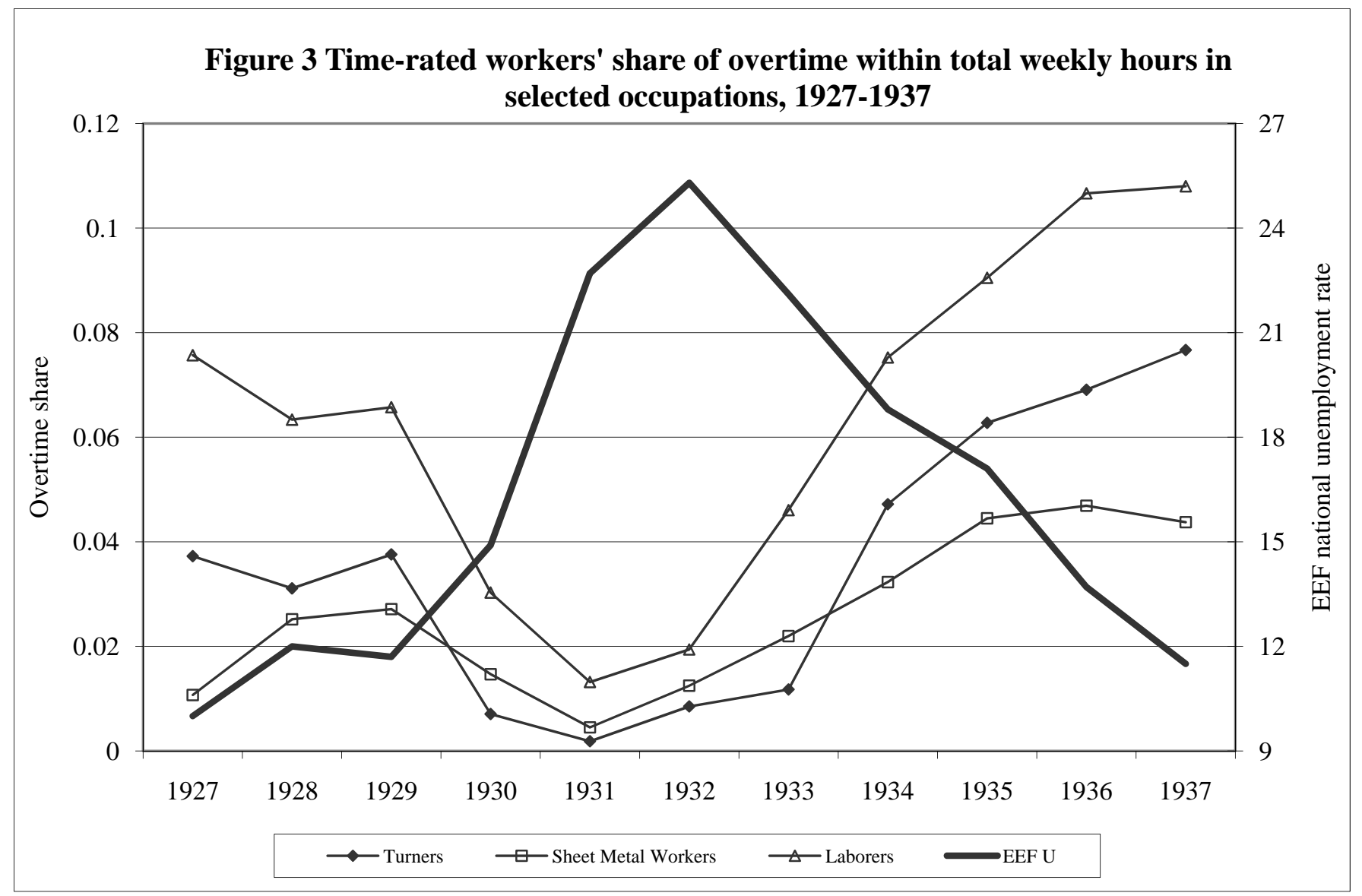


Figure 4 Aggregate hours, prices, wages, and unemployment, 1927-1937 [timeworkers = t/w; pieceworkers = p/w]

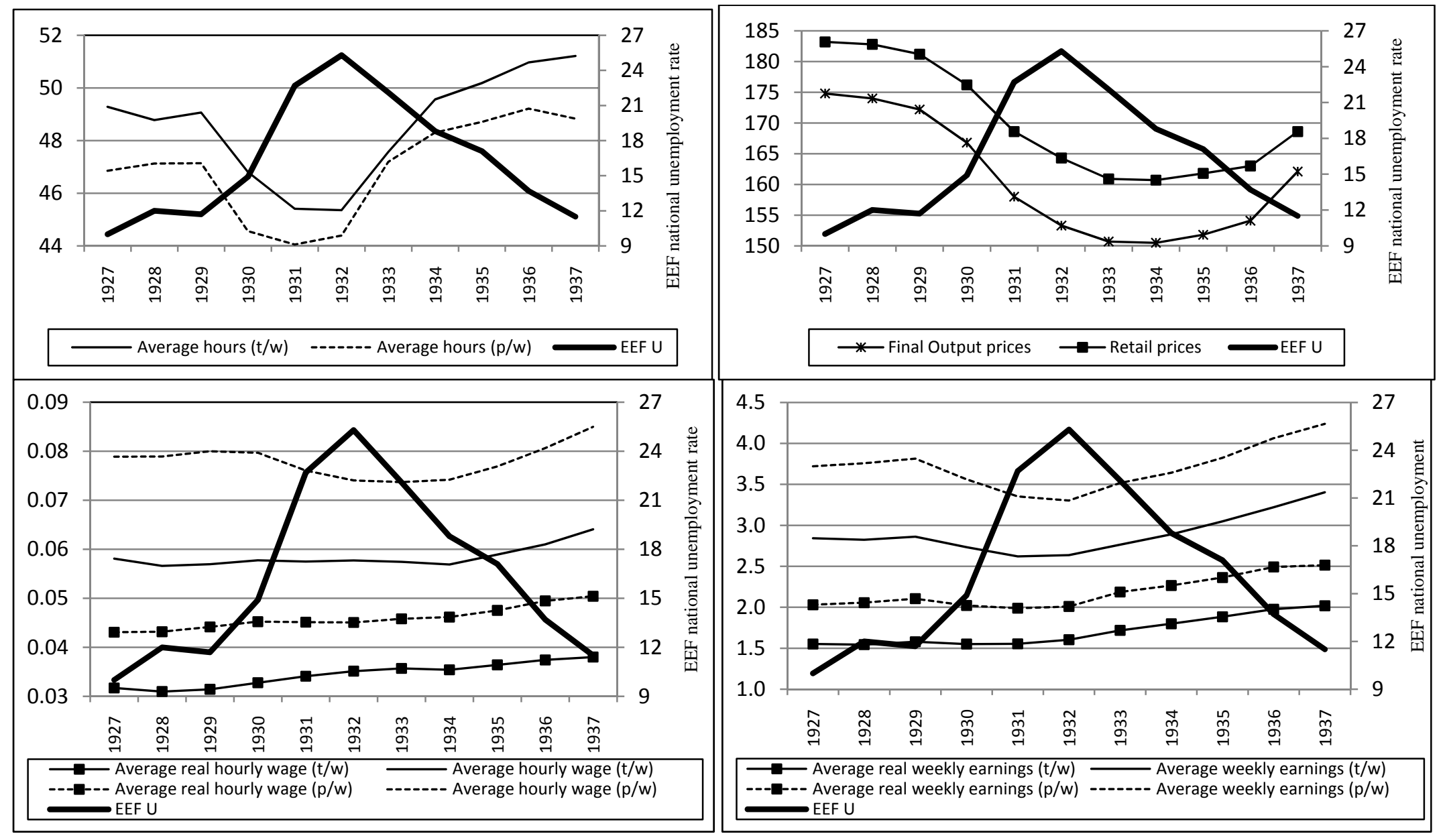




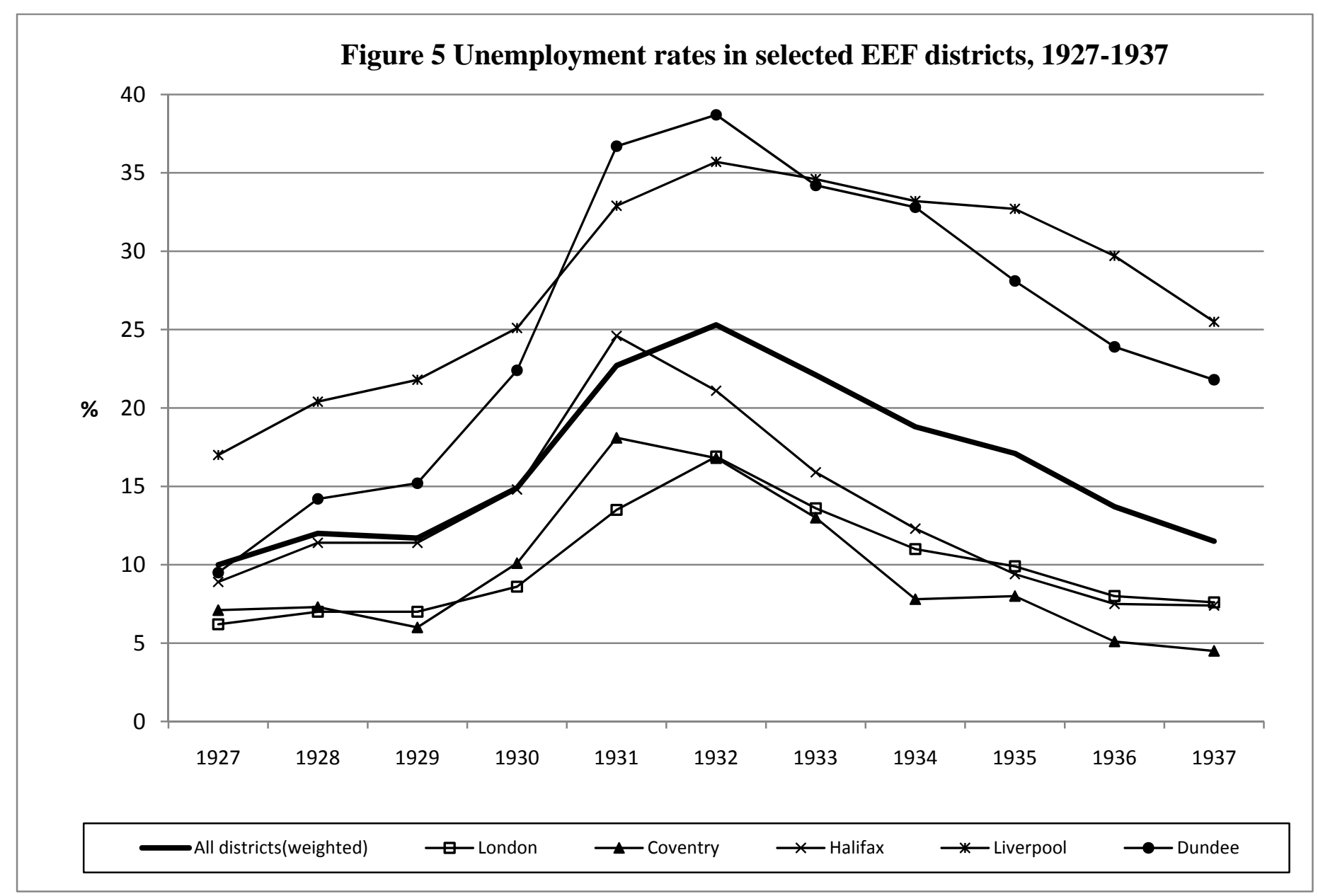


Table 1 Industries, Occupations, Engineering Sections and Engineering Districts covered in the Inter-War EEF Payroll Data

\begin{tabular}{|c|c|}
\hline $\begin{array}{l}\text { Industries } \\
\text { covered by EEF } \\
\text { membership } \\
\text { (Using Ministry } \\
\text { of Labor } \\
\text { classifications) }\end{array}$ & $\begin{array}{l}\text { Heating and Ventilation Apparatus; Scientific \& Photography; Motor Vehicles, Cycles \& } \\
\text { Aircraft; Metal; Industries not separately specified; Constructional Engineering; Iron \& Steel } \\
\text { Tubes; Stove, Grate, Pipe etc \& general Iron Founding; Explosives; Hand Tools, Cutlery, Saws, } \\
\text { Files; Marine Engineering; Brass, Copper, Zinc, Tin, Lead etc.; General Engineering; Brass and } \\
\text { Allied Metal Wares; Watches, Clocks, Plate, Jeweler etc.; Wire, Wire Netting, Wire Ropes; Steel } \\
\text { Melting \& Iron Puddling, Iron \& Steel Rolling and Forging; Bolts, Nuts, Screws, Rivets, Nails etc.; } \\
\text { Tin Plate; Carriages, carts etc. }\end{array}$ \\
\hline Occupations & $\begin{array}{l}\text { Coppersmiths; Fitters; Fitters (other than skilled); Fitters (skilled); Toolroom Fitters; } \\
\text { Machinemen (rated at or above fitter's rate); Machinemen (rated below a fitter's rate); } \\
\text { Moulders; Moulders (loose pattern); Patternmakers; Platers/Riveters/Caulkers; Sheet Metal } \\
\text { Workers; Turners; Laborers. }\end{array}$ \\
\hline $\begin{array}{l}\text { Engineering } \\
\text { Sections }\end{array}$ & $\begin{array}{l}\text { Agricultural engineering; Aircraft manufacture; Allied trades; Boilermakers; Brassfounders; } \\
\text { Construction engineering; Coppersmiths; Drop forgers; Electrical engineering; Founders; Gas } \\
\text { meter makers; General engineering (heavy); General engineering (light); Instrument makers; } \\
\text { Lamp manufacture; Lift manufacture; Locomotive manufacture; Machine tool makers; Marine } \\
\text { engineering; Miscellaneous; Motors: cars, cycles etc.; Motors (commercial); Scale, beam etc. } \\
\text { makers; Sheet metal workers; Tank and gasholder makers; Telephone manufacture; Textile } \\
\text { machinery makers; Vehicle builders. }\end{array}$ \\
\hline $\begin{array}{l}\text { Engineering } \\
\text { Districts } §\end{array}$ & $\begin{array}{l}\text { Aberdeen; Barrow; Bedford; Belfast Marine; Birkenhead; Birmingham, Blackburn; Bolton; } \\
\text { Border Counties; Bradford; Burnley; Burton, Cambridge, Chester, Coventry; Derby; Doncaster; } \\
\text { Dublin, Dundee; East Anglia; East Scotland; Grantham; Halifax; Heavy Woollen; Huddersfield; } \\
\text { Hull; Keighly; Kilmarnock; Leeds; Leicester; Lincoln; Liverpool; London; Manchester; North } \\
\text { East Coast; Northern Ireland; North Staffs, North West Scotland, Nottingham; Oldham; Otley; } \\
\text { Outer London; Peterborough; Preston; Rochdale; St Helens; Sheffield; Shropshire; Wakefield; } \\
\text { West of England; Wigan. }\end{array}$ \\
\hline
\end{tabular}

Note: $\S$ Bold face denotes the 29 districts for which we have matching unemployment rates. 
Table 2 Summary statistics of EEF payroll data

\begin{tabular}{|c|c|c|c|c|c|c|}
\hline & \multicolumn{2}{|c|}{$1927-1937$} & \multicolumn{2}{|c|}{$1930-1933$} & \multicolumn{2}{|c|}{$1934-1937$} \\
\hline & Piecework & Timework & Piecework & Timework & Piecework & Timework \\
\hline $\begin{array}{l}\text { Mean number of } \\
\text { workers per } \\
\text { district (standard } \\
\text { deviation) }\end{array}$ & $\begin{array}{c}357 \\
(605)\end{array}$ & $\begin{array}{c}316 \\
(671)\end{array}$ & $\begin{array}{c}258 \\
(465)\end{array}$ & $\begin{array}{c}240 \\
(498)\end{array}$ & $\begin{array}{c}382 \\
(675)\end{array}$ & $\begin{array}{c}285 \\
(659)\end{array}$ \\
\hline $\begin{array}{l}\text { Percentage } \\
\text { pieceworkers to } \\
\text { total workers }\end{array}$ & \multicolumn{2}{|c|}{53} & \multicolumn{2}{|c|}{51} & \multicolumn{2}{|c|}{57} \\
\hline $\begin{array}{l}\text { Mean percentage } \\
\text { difference in } \\
\text { piecework and } \\
\text { timework average } \\
\text { hourly earnings }\end{array}$ & \multicolumn{2}{|c|}{24.9} & \multicolumn{2}{|c|}{23.7} & \multicolumn{2}{|c|}{23.0} \\
\hline $\begin{array}{l}\text { Average total } \\
\text { weekly hours }\end{array}$ & $\begin{array}{l}47.5 \\
(3.6)\end{array}$ & $\begin{array}{l}49.1 \\
(3.8)\end{array}$ & $\begin{array}{l}45.2 \\
(3.7)\end{array}$ & $\begin{array}{l}46.5 \\
(3.7)\end{array}$ & $\begin{array}{l}48.8 \\
(2.8)\end{array}$ & $\begin{array}{l}50.7 \\
(2.8)\end{array}$ \\
\hline $\begin{array}{l}\text { Average weekly } \\
\text { overtime hours }\end{array}$ & $\begin{array}{c}1.5 \\
(1.8)\end{array}$ & $\begin{array}{l}2.8 \\
(2.4)\end{array}$ & $\begin{array}{c}0.5 \\
(1.2)\end{array}$ & $\begin{array}{l}1.0 \\
(1.6)\end{array}$ & $\begin{array}{c}2.2 \\
(1.8)\end{array}$ & $\begin{array}{c}3.9 \\
(2.3)\end{array}$ \\
\hline $\begin{array}{l}\text { Mean } \Delta \text { log } \\
\text { (weekly hours) }\end{array}$ & $\begin{array}{c}0.6 \\
(7.1)\end{array}$ & $\begin{array}{c}0.9 \\
(8.6)\end{array}$ & $\begin{array}{c}0.2 \\
(9.3)\end{array}$ & $\begin{array}{l}-0.8 \\
(8.1)\end{array}$ & $\begin{array}{c}0.4 \\
(5.5)\end{array}$ & $\begin{array}{c}1.5 \\
(4.3)\end{array}$ \\
\hline $\begin{array}{l}\text { Mean } \Delta \text { log (real } \\
\text { weekly earnings) }\end{array}$ & $\begin{array}{c}3.1 \\
(8.3)\end{array}$ & $\begin{array}{l}3.7 \\
(7.1)\end{array}$ & $\begin{array}{c}1.8 \\
(10.2)\end{array}$ & $\begin{array}{c}1.5 \\
(8.5)\end{array}$ & $\begin{array}{c}3.7 \\
(7.2)\end{array}$ & $\begin{array}{c}4.5 \\
(4.9)\end{array}$ \\
\hline
\end{tabular}


Table 3 Real hourly earnings cyclicality: EEF, 1927-1937

\begin{tabular}{|c|c|c|c|}
\hline $\begin{array}{l}\text { Pay Group [regression } \\
\text { equation(s)] }\end{array}$ & $\begin{array}{l}\text { Consumer price } \\
\text { index deflator }\end{array}$ & $\begin{array}{l}\text { Final output price } \\
\text { deflator }\end{array}$ & $\begin{array}{l}\text { Observations } \\
\text { [step 1, step 2] }\end{array}$ \\
\hline Pieceworkers [Equ. (2)] & $\begin{array}{c}-0.314 \\
(0.058)^{* *}\end{array}$ & $\begin{array}{c}-0.223 \\
(0.054)^{* *}\end{array}$ & 11 \\
\hline Timeworkers [Equ. (2)] & $\begin{array}{l}-0.010 \\
(0.195)\end{array}$ & $\begin{array}{l}-0.006 \\
(0.203)\end{array}$ & 11 \\
\hline Pieceworkers [Equ. (3),(4)] & $\begin{array}{c}-0.322 \\
(0.071)^{* *}\end{array}$ & $\begin{array}{c}-0.246 \\
(0.080)^{* *}\end{array}$ & 2410,11 \\
\hline Timeworkers [Equ. (3),(4)] & $\begin{array}{l}-0.225 \\
(0.245)\end{array}$ & $\begin{array}{l}-0.140 \\
(0.256)\end{array}$ & 2906,11 \\
\hline $\begin{array}{l}\text { Pay Group [regression } \\
\text { equation(s)] }\end{array}$ & \multicolumn{2}{|c|}{$\begin{array}{c}\text { Price deflation through cross-section and } \\
\text { time-series dummy variables }\end{array}$} & $\begin{array}{l}\text { Observations } \\
\text { [step 1, step 2] }\end{array}$ \\
\hline Pieceworkers [Equ. (5),(6)] & \multicolumn{2}{|c|}{$\begin{array}{c}-0.288 \\
(0.062)^{* *}\end{array}$} & 1713,285 \\
\hline Timeworkers [Equ. (5),(6)] & \multicolumn{2}{|c|}{$\begin{array}{l}-0.062 \\
(0.032)\end{array}$} & 1876,305 \\
\hline
\end{tabular}

Notes: Robust standard errors in brackets with ${ }^{* *}$ indicating 0.01 significance on two-tail test. Price deflators are obtained from Feinstein (1972, Table 61). 
Table 4 Real earnings cyclicality: NESPD, males, 1976-1990

\begin{tabular}{|l|c|c|}
\hline $\begin{array}{l}\text { Wage specification (sample } \\
\text { coverage) }\end{array}$ & Total NESPD sample & $\begin{array}{c}\text { Plant and machine } \\
\text { operatives }\end{array}$ \\
\hline $\begin{array}{l}\text { First differenced real hourly } \\
\text { earnings aggregated across all } \\
\text { individuals }\end{array}$ & -1.824 & -1.839 \\
\hline $\begin{array}{l}\text { Real hourly earnings using } \\
\text { individual fixed effects }\end{array}$ & $(1.262)$ & $(1.046)$ \\
\hline $\begin{array}{l}\text { Real hourly earnings using } \\
\text { individual observations and } \\
\text { occupation dummies }\end{array}$ & -2.544 \\
\hline $\begin{array}{l}\text { Real weekly earnings using } \\
\text { individual fixed effects }\end{array}$ & $(0.067)^{* *}$ & -2.167 \\
& $(0.258)^{* *}$ & -2.122 \\
\hline
\end{tabular}

Notes: All regressions include a constant, a time trend and the first differenced national unemployment rate. Robust standard errors in brackets with ** indicating 0.01 significance on two-tail test.

Occupations are at 3-digit level. Unemployment is the national claimant count rate, Office for National Statistics. These estimates cover a sub-period of the 1975-2001 panel data series originally investigated by Devereux and Hart (2006). These authors provide a plot of the annual rate of change of unemployment (see Figure 1 of the Devereux and Hart paper) together with more detailed background descriptive information. 
Table 5 Real weekly earnings cyclicality: EEF, 1927-1937

\begin{tabular}{|c|c|c|c|}
\hline $\begin{array}{l}\text { Pay Group [regression } \\
\text { equation(s)] }\end{array}$ & $\begin{array}{l}\text { Consumer price } \\
\text { index deflator }\end{array}$ & $\begin{array}{l}\text { Final output price } \\
\text { deflator }\end{array}$ & $\begin{array}{l}\text { Observations } \\
\text { [step 1, step 2] }\end{array}$ \\
\hline Pieceworkers [Equ. (2)] & $\begin{array}{c}-0.805 \\
(0.194)^{* *}\end{array}$ & $\begin{array}{c}-0.714 \\
(0.208)^{* *}\end{array}$ & 11 \\
\hline Timeworkers [Equ. (2)] & $\begin{array}{c}-0.827 \\
(0.309)^{* *}\end{array}$ & $\begin{array}{c}-0.736 \\
(0.323)^{*}\end{array}$ & 11 \\
\hline Pieceworkers [Equ. (3),(4)] & $\begin{array}{c}-1.050 \\
(0.382)^{* *}\end{array}$ & $\begin{array}{c}-0.974 \\
(0.402)^{*}\end{array}$ & 2410,11 \\
\hline Timeworkers [Equ. (3),(4)] & $\begin{array}{c}-1.151 \\
(0.464)^{* *}\end{array}$ & $\begin{array}{c}-1.067 \\
(0.482)^{*}\end{array}$ & 2906,11 \\
\hline $\begin{array}{l}\text { Pay Group [regression } \\
\text { equation(s)] }\end{array}$ & \multicolumn{2}{|c|}{$\begin{array}{c}\text { Price deflation through cross-section and } \\
\text { time-series dummy variables }\end{array}$} & $\begin{array}{l}\text { Observations } \\
\text { [step 1, step 2] }\end{array}$ \\
\hline Pieceworkers [Equ. (5),(6)] & \multicolumn{2}{|c|}{$\begin{array}{c}-0.770 \\
(0.227)^{* *}\end{array}$} & 1713,285 \\
\hline Timeworkers [Equ. (5),(6)] & \multicolumn{2}{|c|}{$\begin{array}{c}-0.589 \\
(0.134)^{* *}\end{array}$} & 1876,305 \\
\hline
\end{tabular}

Notes: " Real weekly earnings replace real hourly earnings in each of the equation specifications . Robust standard errors in brackets with ${ }^{* *}(*)$ indicating $0.01(0.05)$ significance on two-tail test. Price deflators are obtained from Feinstein (1972, Table 61). 